\title{
Adsorption Kinetics of Ethyl Mercaptan Found in Commercially Available LPG in UAE
}

\author{
Sulaiman Al-Zuhair ${ }^{1, *}$, Mohamed Abujayyab ${ }^{1}$, Abbas Khaleel ${ }^{2}$ \\ ${ }^{1}$ Chemical Engineering Department, College of Engineering, UAE University, UAE \\ ${ }^{2}$ Chemistry Department, UAE University, UAE
}

Copyright $(2016$ by authors, all rights reserved. Authors agree that this article remains permanently open access under the terms of the Creative Commons Attribution License 4.0 International License

\begin{abstract}
The kinetics of adsorption of ethyl mercaptan, found in commercially available LPG, on different adsorbents, namely Zeolite, $\mathrm{ZnO}$ and house made date pits activated carbon (DP-AC) have been studied. The bed capacity was determined using two adsorbents weights, namely 0.2 and $0.3 \mathrm{~g}$, at different LPG flow rates in the range of 35 to $90 \mathrm{ml} \mathrm{min}^{-1}$. It was found that the capacity of DP-AC and Zeolite did not change with the flow rate due to their much larger micropore volumes and smaller average pores sizes, compared to $\mathrm{ZnO}$. The capacity of DP-AC did not even change with the amount of adsorbate used. Two kinetics models, namely Adam's-Bohart and Yoon-Nelson, were used to fit the experimental data and compared to the first order model. The first order and Adam's-Bohart models did not present the experimental data fairly well, and only the Yoon-Nelson model was able to mimic the sigmoidal trend of the breakthrough curves. The goodness of the fitting of the Yoon-Nelson model was also reflected on the values of the coefficient of determination $\mathrm{R}^{2}$, which was much closer to 1.0 compared to that of the other model. The developed models can be used in designing and scaling-up of fixed-bed adsorption columns.
\end{abstract}

Keywords Ethyl Mercaptan, Commercial LPG, Adsorption Kinetics, Model Fittings

\section{Introduction}

For safety reasons, ethyl mercaptan (EM) is deliberately added as an odorant in commercially available LPG in the UAE. The presence of this sulfur compounds limits the use of LPG for hydrogen production in compact fuel cells (CFC) units. Even at very low concentrations of about $20 \mathrm{ppb}$ [1], EM poisons the catalysts used in the steam reforming. Therefore, all commercial CFC units, which use LPG as feedstock, have their own desulfurization units. EM content in LPG commercially available in UAE is in the range of 20 200 ppm. However, most desulfurization units in CFC units work efficiently only when sulfur content does not exceed 20 ppm. Therefore, it is important to develop an efficient desulfurization system capable of handling LPG of high sulfur contents. Adsorption of sulfur compounds at low temperatures and pressures have been attracting attention for use in CFC units [2-3].

Zeolites have been successfully used to adsorb sulfur compounds in liquid solvents. Thiophenic sulfur compounds found in normal alkane liquid solvents were adsorbed using Zeolite with a capacity in the range of $0.69-1.62 \mathrm{mmol} \mathrm{S} \mathrm{g}^{-1}$ [4]. Lidan et al [5] used metal salts impregnated Zeolites in a fixed bed continuous system, with 5 wt $\% \quad \mathrm{Ag}_{2} \mathrm{O} / \mathrm{NaY}$ showing the highest capacity $\left(87.9 \mathrm{mg} \mathrm{g}^{-1}\right)$. The capacity of this adsorbent dropped to $64.39 \mathrm{mg} \mathrm{g}^{-1}$ when tested with a real LPG, composed mainly of propane (39.7\%), i-butane $(24.8 \%)$ and $n$-butane $(11.3 \%)$ and having a total sulfur of about 230 ppm, consisting mainly of dimethyldisulfide (DMDS) (more than 80\%). It should be noted though that this test was performed under a pressure of $1 \mathrm{MPa}$ to ensure liquid phase adsorption.

On the other hand, activated carbon (AC), has been used to remove sulfur compounds from gaseous solvents. Vega et al [6] tested commercially available AC for adsorption of EM with initial concentration of $4 \mathrm{ppm}$, in pure $\mathrm{N}_{2}$ with a flow rate of $250 \mathrm{ml} \mathrm{min}^{-1}$. The adsorption capacity and saturation time of $0.25 \mathrm{~g} \mathrm{AC}$, without impregnation, were $30 \mathrm{mg} \mathrm{g}^{-1}$ and $3480 \mathrm{~min}$. AC, from coconut shell, was also studied in adsorption of sulfur compounds, with an input concentration of 0.1-0.4 ppm, from pipelined synthetic natural gas with flow rates in the range of 4.0-4.5 $1 \mathrm{~min}^{-1}$. The adsorption capacity and saturation time of $0.25 \mathrm{~g} \mathrm{AC}$, without impregnation, for adsorption of EM were $0.07 \mathrm{mg}$ sulfur $\mathrm{g}^{-1}$ (equivalent to $0.13 \mathrm{mg} \mathrm{EM} \mathrm{g}^{-1}$ ) and $7000 \mathrm{~min}$ [6].

Kinetics models for the adsorption of sulfur compounds from diesel using $\mathrm{AC}$ (wood based with $\mathrm{H}_{3} \mathrm{PO}_{4}$ activation) have been developed by Wen et al [7] using a first order and a second order kinetics. Two sulfur compounds, namely dibenzothiophene (DBT) and 4,6-dimethyldibenzothiophene (4,6-DMDBT) were tested, in a fixed bed of $0.5 \mathrm{~g} \mathrm{AC}$, in the presence and absence of nitrogen. The flow of the simulated 


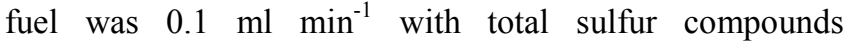
concentration of $761.6 \mathrm{ppmw}$. The adsorption capacity of the AC was found to be around $0.85 \mathrm{mmol}$ sulfur $\mathrm{g}^{-1}\left(168 \mathrm{mg} \mathrm{g}^{-1}\right)$ but drops to $0.3 \mathrm{mmol}$ sulfur $\mathrm{g}^{-1}\left(59 \mathrm{mg} \mathrm{g}^{-1}\right)$ in the presence of nitrogen, and the breakthrough time was $300 \mathrm{~min}$. The first order kinetics represented the system better than the second order, and the kinetics constants of DBT and 4,6-DMDBT for first order kinetics were found to be 0.0492 and 0.0751 $\mathrm{min}^{-1}$, respectively. The second order kinetics constants for DBT and 4,6-DMDBT were found to be 0.1753 and $0.0751 \mathrm{~g}$ $\mathrm{mmol}^{-1} \mathrm{~min}^{-1}$, respectively.

In our previous paper [3], the EM adsorption efficiency of Zeolite, $\mathrm{ZnO}$ and DP-AC was evaluated. A first order kinetics model was developed and used to describe the sulfur adsorption in packed bed column. The model presented the experimental data fairly well, however it was unable to mimic the sigmoidal trend of the breakthrough curves. Therefore, in order to accurately design and scale-up a fixed-bed adsorption column for EM removal, a better model prediction is required. The main objective of this paper is to develop a reliable model that more accurately predicts the behavior in a continuous adsorption column. In addition, selected textural properties of the adsorbents are characterized and discussed.

\section{Materials and Methods}

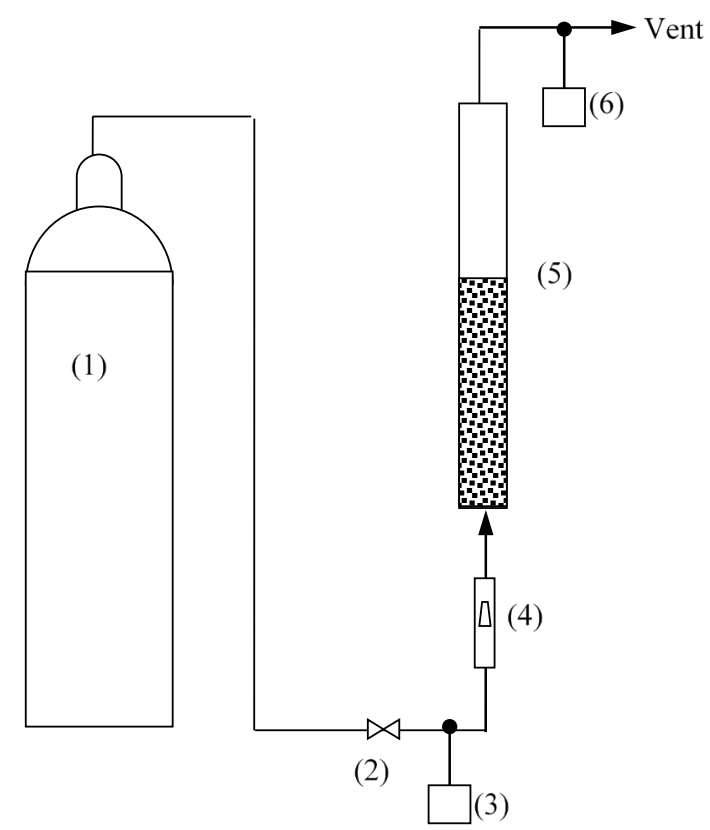

Figure 1. Schematic diagram of experimental set-up: (1) LPG cylinder, (2) valve, (3) sampling port, (4) flow meter, (5) absorption column and (6) sampling port

The experimental procedure is described in details in our previous paper [3]. Briefly, the LPG flows from a cylinder, obtained from a local petrol station, ADNOC, UAE, and goes through a valve to regulate the flow rate, which is measured using a flow meter. A sampling port is located after the valve, where the sulfur content in the LPG cylinder can be measured. The gas goes through the adsorption column, which is filled with a specific amount of adsorbent, and then passes through another sampling port before being vented. The experimental set-up is shown in Figure 1.

Three types of adsorbents were tested, namely Zeolite (1.5 mm diameter granules and a density of $0.61 \mathrm{~kg} \mathrm{~m}^{-3}$ ), $\mathrm{ZnO}$ (1-2 mm diameter and a density of $1.32 \mathrm{~kg} \mathrm{~m}^{-3}$ ), which were kindly provided by JX-NRI, Japan, and house made date pits AC (DP-AC) (0.6-0.65 mm diameter and a density of $0.57 \mathrm{~kg} \mathrm{~m}^{-3}$ ). The procedure for preparing the DP-AC can be found in our previous paper [3]. The desulfurization was tested using two weights of the adsorbents $(0.2$ and 0.3 g) at different LPG flow rates $\left(35-80 \mathrm{ml} \mathrm{min}^{-1}\right)$ in a glass tube of $0.38 \mathrm{~cm}$ internal diameter. Porosity and BET specific surface area were obtained using N2 adsorption at $77 \mathrm{~K}$ on a Quantachrome Autosob-1 volumetric gas sorption instrument. Samples were degassed at $150{ }^{\circ} \mathrm{C}$ for 1 hr before each measurement.

Gas Chromatograph (Shimadzu, GC-2014) equipped with FPD detector and a RT-XL column was used to determine the sulfur compounds. The detector and injector temperatures were set at $150{ }^{\circ} \mathrm{C}$ and $250{ }^{\circ} \mathrm{C}$, respectively. The column temperature was kept at $60{ }^{\circ} \mathrm{C}$ for 1 minute, then increased to $250{ }^{\circ} \mathrm{C}$ at a rate of $10{ }^{\circ} \mathrm{C} \mathrm{min}{ }^{-1}$. The GC was calibrated using a gas mixture containing 10\%, EM, together with other sulfur compounds, in $\mathrm{N}_{2}$ balance, which was obtained from Nahla Medical Supplies, UAE. All results presented are the averages of at least duplicate runs, and the reproducibility is confirmed from the error bars shown in the results. Characterized and discussed.

\section{Results and Discussions}

\subsection{BET Surface Area and Porosity Characteristics}

The $\mathrm{N}_{2}$ adsorption-desorption isotherms of Zeolite, DP-AC and $\mathrm{ZnO}$ are shown in Figure 2 and selected textural properties are presented in Table 1. The Zeolite showed a type-I (IUPAC classification) isotherm exhibiting a sharp uptake in the low relative pressure region, which is a typical feature of microporous materials. This is also confirmed by its BJH pore size distribution shown in Figure 3 which shows homogeneous distribution in the micropores range, less than $2.5 \mathrm{~nm}$. Similarly, DP-AC showed a significant amount of micropores indicated by a significant adsorption of nitrogen at low relative pressures, which are also reflected in its pores size distribution shown in Figure 3. In addition, DP-AC showed significant mesoporosity as indicated by the hysteresis loop in its isotherm. This type of bimodal porosity would be useful in adsorption where the mesopores would enhance intra-particle diffusion. On the other hand, $\mathrm{ZnO}$ showed a typical type-IV isotherm with a hysteresis loop that indicates the dominance of mesopores with negligible amount of micropores as shown in Table 1 and Figure 3. The hysteresis loop appeared at high relative 
pressures, above 0.7 , indicating relatively large average pore diameter, which is also confirmed by its pore size distribution plot in Figure 3. The relatively low surface area of $\mathrm{ZnO}$ correlates with the absence of small mesopores and micropores as compared with the microporous Zeolites and micro-mesoporous DP-AC. The porosity of $\mathrm{ZnO}$ results mainly from inter-particle pores in the aggregates of primary particles.

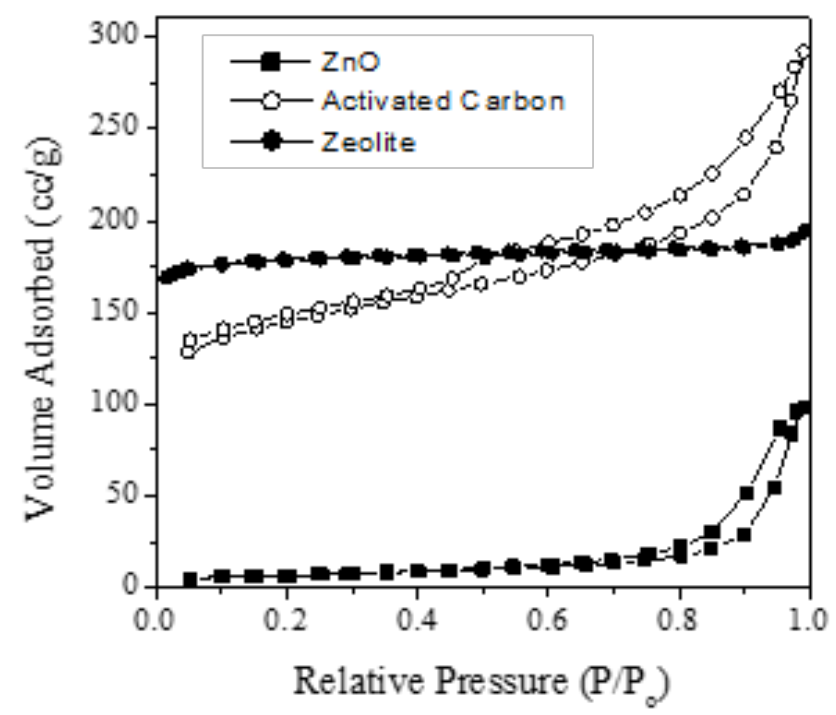

Figure 2. $\mathrm{N}_{2}$ adsorption-desorption isotherms of Zeolite, DP-AC and $\mathrm{ZnO}$

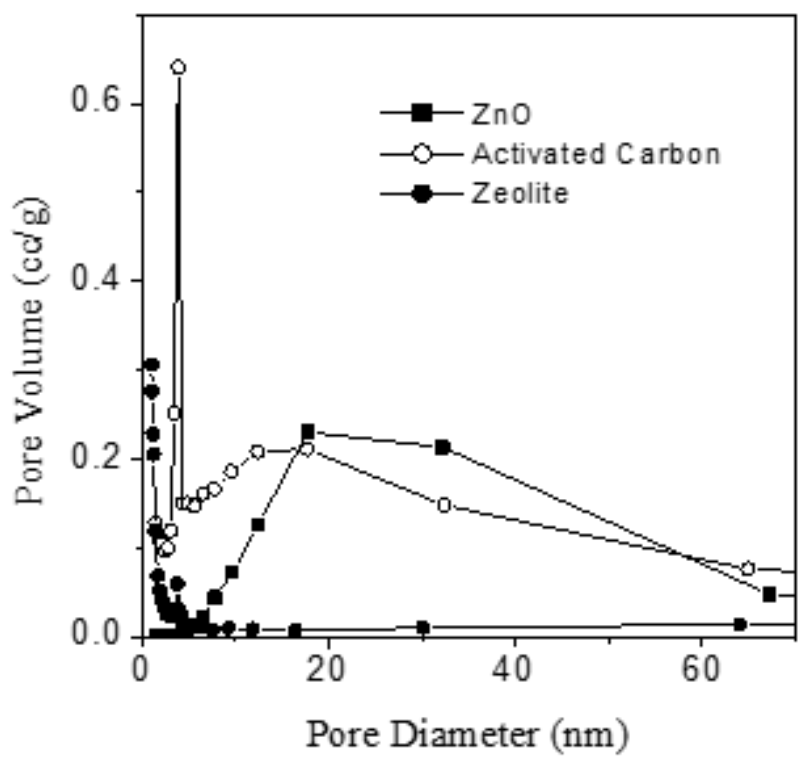

Figure 3. BJH pore size distribution of Zeolite, DP-AC and $\mathrm{ZnO}$

Table 1. BET surface area and pore characteristics of Zeolite, DP-AC and $\mathrm{ZnO}$

\begin{tabular}{|c|c|c|c|c|}
\hline Composite & $\begin{array}{c}\mathrm{S}_{\mathrm{BET}} \\
\left(\mathrm{m}^{2} \mathrm{~g}^{-1}\right)\end{array}$ & $\begin{array}{c}\text { Pore } \\
\text { volume } \\
\left(\mathrm{cm}^{3} \mathrm{~g}^{-1}\right)\end{array}$ & $\begin{array}{c}\text { Micropore } \\
\text { volume } \\
\left(\mathrm{cm}^{3} \mathrm{~g}^{-1}\right)\end{array}$ & $\begin{array}{c}\text { Pore size } \\
(\mathrm{nm})\end{array}$ \\
\hline Zeolite & 529 & 0.29 & 0.25 & 2.2 \\
\hline DP-AC & 441 & 0.41 & 0.14 & 3.7 \\
\hline $\mathrm{ZnO}$ & 24 & 0.13 & 0.006 & 21.8 \\
\hline
\end{tabular}

\subsection{Desulfurization Characteristics}

The desulfurization characteristics, of different adsorbents at different flow rates, were studied using the glass tube reactor loaded with 0.2 or $0.3 \mathrm{~g}$ adsorbent. In these experiments, Zeolite, DP-AC and $\mathrm{ZnO}$ were tested and compared at different flow rates. Figures 4-6 show samples of the results for Zeolite, DP-AC and $\mathrm{ZnO}$, respectively, at $0.2 \mathrm{~g}$ adsorbents at (a) 60 and (b) $80 \mathrm{ml}$ $\min ^{-1}$. All results are the averages of at least two duplicate runs, with the error bars that confirm the reproducibility of the results. The results at other conditions are shown in our previous paper [3]

\subsubsection{Bed capacity}

The bed capacity, $\mathrm{q}_{\mathrm{e}}\left(\mathrm{mg} \mathrm{g}^{-1}\right)$ is determined using Eq (1)

$$
\mathrm{q}_{\mathrm{e}}=\frac{\mathrm{C}_{\text {in }} \dot{\mathrm{V}}_{\mathrm{LPG}} \rho_{\mathrm{LPG}}}{\mathrm{m}_{\mathrm{b}}} \int_{0}^{\mathrm{t}}\left(1-\frac{\mathrm{C}_{\mathrm{L}}}{\mathrm{C}_{\mathrm{in}}}\right) \mathrm{dt}
$$

Where, $\rho_{\mathrm{LPG}}\left(\mathrm{g} \mathrm{cm}^{-3}\right)$ is the density of LPG, $\mathrm{C}_{\mathrm{L}}$ and $\mathrm{C}_{\text {in }}$ (mg per $1000 \mathrm{~g}$ ) are the adsorbate fluid-phase concentration at the outlet and inlet, respectively, $\mathrm{m}_{\mathrm{b}}(\mathrm{g})$ is the mass of adsorbent bed and $V_{\text {LPG }}\left(\mathrm{cm}^{3} \mathrm{~min}^{-1}\right)$ is the LPG flow rate. The capacity at each LPG flow rate and adsorbate amount was determined by integrating the curve of $\left(1-C_{L} / C_{i n}\right)$ vs time in minutes, and the results are shown in Figure 4. It was found that the capacity of DP-AC did not change with the amount of adsorbent used, whereas it did for Zeolite and $\mathrm{ZnO}$. The increase in capacity for Zeolite and $\mathrm{ZnO}$ is mainly due to the reduced channeling with the increase in the amount of adsorbent used. This was not significant in DP-AC due to its lower packing density. The effect of increasing the flow rate had an insignificant effect on the capacity of DP-AC and Zeolite, where it significantly affected that of $\mathrm{ZnO}$. The insignificant effect of flow rate on DP-AC and Zeolite adsorption is due to their much larger micropore volumes and smaller average pores sizes, as shown in Table 1. In this case, the adsorption is mainly in the intra-particle micropores, which is not affected by flow rate. However, $\mathrm{ZnO}$ was found to have a negligible microporosity and larger average pores sizes. Therefore, the adsorption is mainly on the external surface, which is affected by the flow rate.

The capacity of Zeolite was in the range of 4.0-8.5 mg g ${ }^{-1}$, which was close to that of $13 \mathrm{X}$ Zeolite of $11.9 \mathrm{mg} \mathrm{g}^{-1}$. However, by impregnating Zeolite with $5 \mathrm{wt} \% \mathrm{Ag}_{2} \mathrm{O}$, the capacity increased to $87.9 \mathrm{mg} \mathrm{g}^{-1}$ [5]. It should be noted that this value was for the adsorption of DMDS in a liquid phase, whereas in the present work the adsorption was for EM in a gas phase. On the other hand, the capacity of DP-AC was found to be in the range of 4.9-6.0 $\mathrm{mg} \mathrm{g}^{-1}$. This is four times less than the capacity of commercially available AC which was $30 \mathrm{mg} \mathrm{g}-1[6]$. This could be mainly due to the larger surface area of the commercially available AC that was reported to be $927 \mathrm{~m}^{2} \mathrm{~g}^{-1}$, which was almost double that of the prepared DP-AC that was $441 \mathrm{~m}^{2} \mathrm{~g}^{-1}$. In addition, in the work of Vega et al [6], the EM was introduced in $\mathrm{N}_{2}$ rather than LPG, and the partition coefficient is expected to be 
different. The AC tested with diesel for the desulfurization of diesel fuel $[7,8]$, showed a much higher capacity and longer breakthrough time. On the other hand, the capacities of alumina and $\mathrm{Ni} / \mathrm{SiO}_{2}-\mathrm{Al}_{2} \mathrm{O}_{3}$ [9] were found to be comparable to that of the DP-AC in this study. As mentioned earlier, it is difficult to compare adsorption from liquids with that from gases of much less sulfur content. In addition, the tested sulfur compounds in the works of Wen et al [9] and Kim et al [10] were DBT and 4,6-DMDBT
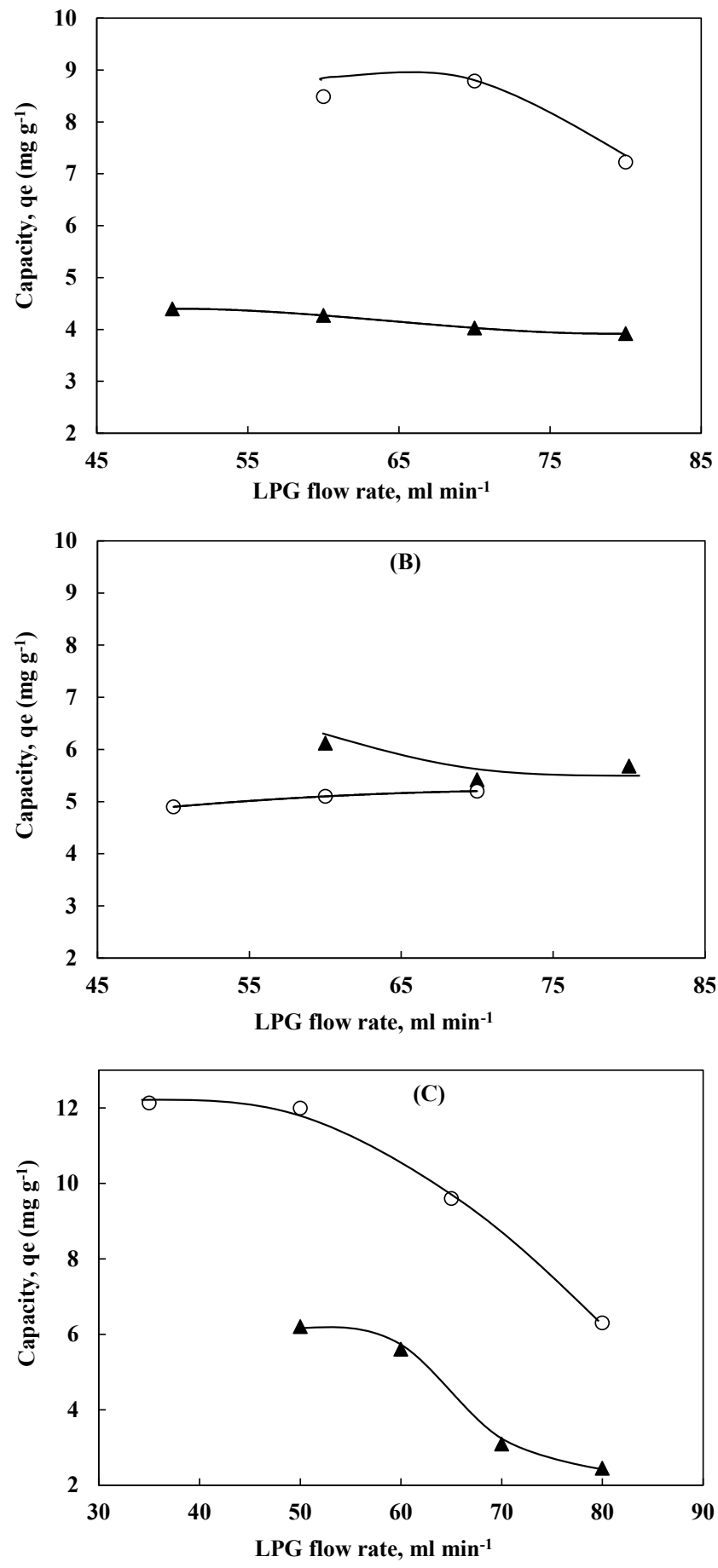

Figure 4. Bed capacities at different flow rates and adsorbents amounts (o $0.3 \mathrm{~g}$ and $\boldsymbol{\Delta} 0.2 \mathrm{~g}$ ), using (A) Zeolite, (B) DP-AC and (C) $\mathrm{ZnO}$

\subsubsection{Kinetics study}

Neglecting axial dispersion compared to convective transport and assuming a first order model, Eq (2) was derived [7]

$$
\frac{\mathrm{C}_{\mathrm{L}}}{\mathrm{C}_{\mathrm{in}}}=1-\mathrm{k} \frac{\rho_{\mathrm{b}} \mathrm{Lq}}{\mathrm{u}_{\mathrm{s}} \mathrm{C}_{\mathrm{in}} \rho_{\mathrm{LPG}}} \exp (-\mathrm{kt})
$$

Where, $\rho_{\mathrm{b}}\left(\mathrm{g} \mathrm{cm}^{-3}\right)$ is the bed bulk density, $\mathrm{k}\left(\mathrm{min}^{-1}\right)$ is a first-order rate constant, $\mathrm{L}(\mathrm{cm})$ is the length of the bed, and us $\left(\mathrm{cm} \mathrm{min}{ }^{-1}\right)$ is the superficial velocity, determined from the LPG flow rate and density, and the cross sectional area of the reactor. The first order kinetics is widely used in adsorption modeling, and was found to represent better the adsorption of sulfur compound from diesel fuel [7]. The first order kinetics constant, $\mathrm{k}$ in Eq (2), was determined, for the three adsorbents at different flow rates, by the least square method. Excel solver was used to minimize the summation of the difference between the squares of the experimental and predicted values of $C_{L} / C_{i n}$. The determined $\mathrm{k}$ values are presented in Tables 2-4 for Zeolite, DP-AC and $\mathrm{ZnO}$, respectively. The tables also show the coefficient of determination, $\mathrm{R}^{2}$, which measures the goodness of the fitting. Graphical outputs showing the fits of the experimental data by the first order model are shown in Figures. 5-7, for $0.2 \mathrm{~g}$ adsorbent at 60 and $80 \mathrm{ml} \mathrm{min}-1$ using Zeolite, DP-AC and $\mathrm{ZnO}$, respectively. Similar trends were observed for other adsorbents.

The first order kinetics did not present the experimental data well, as reflected in the values of $\mathrm{R}^{2}$, shown in Tables $2-4$, that have average values of $0.373 \pm 0.22,0.788 \pm 0.20$ and $0.712 \pm 0.14$ for Zeolite, DP-AC and $\mathrm{ZnO}$, respectively. The figures clearly show that the model could not follow the sigmoidal behavior of the adsorption front. To overcome the problem faced with using the first kinetic model, and to better present the experimental data, two other kinetics models were tested.

\section{A. Adams-Bohart model}

The second tested model was the Adams-Bohart model [11], given in Eq (3).

$$
\frac{\mathrm{C}_{\mathrm{L}}}{\mathrm{C}_{\mathrm{in}}}=\exp \left[\mathrm{k}_{\mathrm{AB}}\left(\mathrm{C}_{\mathrm{in}} \mathrm{t}-\mathrm{q}_{\mathrm{e}} \rho_{\mathrm{b}} \frac{\mathrm{L}}{\mathrm{u}_{\mathrm{s}}}\right)\right]
$$

Where, $\mathrm{k}_{\mathrm{AB}}\left(\mathrm{cm}^{3} \mathrm{~g}^{-1} \mathrm{~min}^{-1}\right)$ is the kinetic constant using a quasi-chemical kinetic rate expression, which was determined, for the three adsorbents at different flow rates, by the least square method. Excel solver was used to minimize the summation of the difference between the squares of the experimental and predicted values of $\mathrm{C}_{\mathrm{L}} / \mathrm{C}_{\mathrm{in}}$. The determined $\mathrm{k}_{\mathrm{AB}}$ values are presented in Tables 2-4 for Zeolite, DP-AC and $\mathrm{ZnO}$, respectively together with the coefficients of determination, $\mathrm{R}^{2}$. Graphical outputs showing the fits of the experimental data by the Adams-Bohart model are shown in Figures. 5-7, for $0.2 \mathrm{~g}$ adsorbent at 60 and $80 \mathrm{ml} \mathrm{min}^{-1}$ using Zeolite, DP-AC and $\mathrm{ZnO}$, respectively. 
It was observed that the value of the first order kinetic constant, $\mathrm{k}$, increases with the increase in flow rate, which is due to mass transfer enhancement. However, the Adams-Bohart kinetic constant $\mathrm{k}_{\mathrm{AB}}$ did not show such a trend, which suggest that mass transfer was not significant in the first period of adsorption. It was also found that $\mathrm{k}$ decreases with the increase in the amount of the adsorbent used, which is due to the decrease in the channeling effect with the increase in the amount of adsorbent. Similar trend was also observed for $\mathrm{k}_{\mathrm{AB}}$ of Zeolite and DP-AC, but not clear for $\mathrm{ZnO}$. This suggests that the channeling was not significant in the earlier part of adsorption on $\mathrm{ZnO}$.

Table 2. Estimated values of adsorption kinetics parameters of 0.2 and $0.3 \mathrm{~g}$ Zeolite at different flowrates

\begin{tabular}{|c|c|c|c|c|}
\hline \multirow{2}{*}{ Adsorbent } & \multicolumn{4}{|c|}{ Flow rate $\left(\mathrm{ml} \mathrm{min}^{-1}\right)$} \\
\hline & 50 & 60 & 70 & 80 \\
\hline \multicolumn{5}{|c|}{$0.2 \mathrm{~g}$} \\
\hline $\begin{array}{l}\text { First order } \\
\mathrm{k}\left(\mathrm{min}^{-1}\right)\end{array}$ & $\begin{array}{c}\mathrm{k}=0.0034 \\
\mathrm{R}^{2}=0.324\end{array}$ & $\begin{array}{c}\mathrm{k}=0.0041 \\
\mathrm{R}^{2}=0.389\end{array}$ & $\begin{array}{c}\mathrm{k}=0.0045 \\
\mathrm{R}^{2}=0.711\end{array}$ & $\begin{array}{c}\mathrm{k}=0.0062 \\
\mathrm{R}^{2}=0.723\end{array}$ \\
\hline $\begin{array}{l}\text { Adams-Bohart, } \mathrm{k}_{\mathrm{AB}} \\
\left(\mathrm{cm}^{3} \mathrm{~g}^{-1} \mathrm{~min}^{-1}\right)\end{array}$ & $\begin{array}{l}\mathrm{k}_{\mathrm{AB}}=86157 \\
\mathrm{R}^{2}=0.904\end{array}$ & $\begin{array}{l}\mathrm{k}_{\mathrm{AB}}=83234 \\
\mathrm{R}^{2}=0.887\end{array}$ & $\begin{array}{l}\mathrm{k}_{\mathrm{AB}}=71644 \\
\mathrm{R}^{2}=0.756\end{array}$ & $\begin{array}{l}\mathrm{k}_{\mathrm{AB}}=82822 \\
\mathrm{R}^{2}=0.262\end{array}$ \\
\hline $\begin{array}{c}\text { Yoon-Nelson } \\
\mathrm{k}_{\mathrm{YN}}\left(\mathrm{min}^{-1}\right) \\
\tau(\mathrm{min}) \\
\end{array}$ & $\begin{aligned} & \mathrm{k}_{\mathrm{YN}}=0.0071 \\
& \tau=523.7 \\
& \mathrm{R}^{2}=0.982 \\
&\end{aligned}$ & $\begin{aligned} \mathrm{k}_{\mathrm{YN}} & =0.0097 \\
\tau & =407.4 \\
\mathrm{R}^{2} & =0.986\end{aligned}$ & $\begin{aligned} \mathrm{k}_{\mathrm{YN}} & =0.0088 \\
\tau & =296.6 \\
\mathrm{R}^{2} & =0.984\end{aligned}$ & $\begin{aligned} \mathrm{k}_{\mathrm{YN}} & =0.0030 \\
\tau & =200.4 \\
\mathrm{R}^{2} & =0.987\end{aligned}$ \\
\hline \multicolumn{5}{|c|}{$0.3 \mathrm{~g}$} \\
\hline $\begin{array}{l}\text { First order } \\
\mathrm{k}\left(\mathrm{min}^{-1}\right)\end{array}$ & $\begin{array}{r}\mathrm{k}=0.0019 \\
\mathrm{R}^{2}=0.199\end{array}$ & $\begin{array}{c}\mathrm{k}=0.022 \\
\mathrm{R}^{2}=0.205\end{array}$ & $\begin{array}{l}\mathrm{k}=0.0026 \\
\mathrm{R}^{2}=0.212\end{array}$ & $\begin{aligned} k & =0.0030 \\
R^{2} & =0.224\end{aligned}$ \\
\hline $\begin{array}{c}\text { Adams-Bohart, } \mathrm{k}_{\mathrm{AB}} \\
\left(\mathrm{cm}^{3} \mathrm{~g}^{-1} \mathrm{~min}^{-1}\right)\end{array}$ & $\begin{array}{l}\mathrm{k}_{\mathrm{AB}}=22856 \\
\mathrm{R}^{2}=0.813\end{array}$ & $\begin{array}{l}\mathrm{k}_{\mathrm{AB}}=2823 \\
\mathrm{R}^{2}=0.782\end{array}$ & $\begin{array}{l}\mathrm{k}_{\mathrm{AB}}=22012 \\
\mathrm{R}^{2}=0.773\end{array}$ & $\begin{array}{l}\mathrm{k}_{\mathrm{AB}}=32381 \\
\mathrm{R}^{2}=0.728\end{array}$ \\
\hline $\begin{array}{c}\text { Yoon-Nelson } \\
\mathrm{k}_{\mathrm{YN}}\left(\mathrm{min}^{-1}\right) \\
\tau(\min )\end{array}$ & $\begin{array}{c}\mathrm{k}_{\mathrm{YN}}=0.0066 \\
\tau=823.6 \\
\mathrm{R}^{2}=0.984\end{array}$ & $\begin{aligned} \mathrm{k}_{\mathrm{YN}} & =0.0078 \\
\tau & =7567 \\
\mathrm{R}^{2} & =0.972\end{aligned}$ & $\begin{array}{c}\mathrm{k}_{\mathrm{YN}}=0.0093 \\
\tau=673.9 \\
\mathrm{R}^{2}=0.987\end{array}$ & $\begin{array}{c}\mathrm{k}_{\mathrm{YN}}=0.0085 \\
\tau=529.4 \\
\mathrm{R}^{2}=0.954\end{array}$ \\
\hline
\end{tabular}

Table 3. Estimated values of adsorption kinetics parameters of 0.2 and $0.3 \mathrm{~g}$ DP-AC at different flowrates

\begin{tabular}{|c|c|c|c|c|}
\hline \multirow{2}{*}{ Adsorbent } & \multicolumn{4}{|c|}{ Flow rate $\left(\mathrm{ml} \mathrm{min}^{-1}\right)$} \\
\hline & 50 & 60 & 70 & 80 \\
\hline \multicolumn{5}{|c|}{$0.2 \mathrm{~g}$} \\
\hline $\begin{array}{l}\text { First order } \\
\mathrm{k}\left(\mathrm{min}^{-1}\right)\end{array}$ & - & $\begin{array}{l}\mathrm{k}=0.0065 \\
\mathrm{R}^{2}=0.911\end{array}$ & $\begin{array}{l}\mathrm{k}=0.0076 \\
\mathrm{R}^{2}=0.444\end{array}$ & $\begin{array}{l}\mathrm{k}=0.0077 \\
\mathrm{R}^{2}=0.466\end{array}$ \\
\hline $\begin{array}{l}\text { Adams-Bohart, } \mathrm{k}_{\mathrm{AB}} \\
\left(\mathrm{cm}^{3} \mathrm{~g}^{-1} \mathrm{~min}^{-1}\right)\end{array}$ & - & $\begin{array}{l}\mathrm{k}_{\mathrm{AB}}=89720 \\
\mathrm{R}^{2}=0.665\end{array}$ & $\begin{aligned} \mathrm{k}_{\mathrm{AB}} & =13812 \\
\mathrm{R}^{2} & =0.642\end{aligned}$ & $\begin{array}{l}\mathrm{k}_{\mathrm{AB}}=61135 \\
\mathrm{R}^{2}=0.597\end{array}$ \\
\hline $\begin{array}{c}\text { Yoon-Nelson } \\
\mathrm{k}_{\mathrm{YN}}\left(\mathrm{min}^{-1}\right) \\
\tau(\mathrm{min}) \\
\end{array}$ & - & $\begin{array}{c}\mathrm{k}_{\mathrm{YN}}=0.0169 \\
\tau=165.7 \\
\mathrm{R}^{2}=0.968\end{array}$ & $\begin{aligned} \mathrm{k}_{\mathrm{YN}} & =0.0464 \\
\tau & =156.5 \\
\mathrm{R}^{2} & =0.969\end{aligned}$ & $\begin{aligned} \mathrm{k}_{\mathrm{YN}} & =0.0203 \\
\tau & =187.6 \\
\mathrm{R}^{2} & =0.946\end{aligned}$ \\
\hline \multicolumn{5}{|c|}{$0.3 \mathrm{~g}$} \\
\hline $\begin{array}{l}\text { First order } \\
\mathrm{k}\left(\mathrm{min}^{-1}\right)\end{array}$ & $\begin{array}{l}\mathrm{k}=0.0025 \\
\mathrm{R}^{2}=0.904\end{array}$ & $\begin{aligned} \mathrm{k} & =0.030 \\
\mathrm{R}^{2} & =0.912\end{aligned}$ & $\begin{array}{l}\mathrm{k}=0.0037 \\
\mathrm{R}^{2}=0.917\end{array}$ & $\begin{array}{c}\mathrm{k}=0.0041 \\
\mathrm{R}^{2}=0.965\end{array}$ \\
\hline $\begin{array}{l}\text { Adams-Bohart, } \mathrm{k}_{\mathrm{AB}} \\
\left(\mathrm{cm}^{3} \mathrm{~g}^{-1} \mathrm{~min}^{-1}\right)\end{array}$ & $\begin{array}{c}\mathrm{k}_{\mathrm{AB}}=48840 \\
\mathrm{R}^{2}=0.657\end{array}$ & $\begin{array}{l}\mathrm{k}_{\mathrm{AB}}=34561 \\
\mathrm{R}^{2}=0.624\end{array}$ & $\begin{array}{l}\mathrm{k}_{\mathrm{AB}}=45586 \\
\mathrm{R}^{2}=0.623\end{array}$ & $\begin{aligned} \mathrm{k}_{\mathrm{AB}} & =50391 \\
\mathrm{R}^{2} & =0.624\end{aligned}$ \\
\hline $\begin{array}{c}\text { Yoon-Nelson } \\
\mathrm{k}_{\mathrm{YN}}\left(\mathrm{min}^{-1}\right) \\
\tau(\mathrm{min})\end{array}$ & $\begin{aligned} \mathrm{k}_{\mathrm{YN}} & =0.0106 \\
\tau & =280.9 \\
\mathrm{R}^{2} & =0.941\end{aligned}$ & $\begin{array}{c}\mathrm{k}_{\mathrm{YN}}=0.0189 \\
\tau=235.2 \\
\mathrm{R}^{2}=0.98\end{array}$ & $\begin{aligned} \mathrm{k}_{\mathrm{YN}} & =0.0184 \\
\tau & =199.0 \\
\mathrm{R}^{2} & =0.989\end{aligned}$ & $\begin{array}{c}\mathrm{k}_{\mathrm{YN}}=0.0183 \\
\tau=172.6 \\
\mathrm{R}^{2}=0.983\end{array}$ \\
\hline
\end{tabular}


Table 4. Estimated values of adsorption kinetics parameters of 0.2 and $0.3 \mathrm{~g} \mathrm{ZnO}$ at different flowrates

\begin{tabular}{|c|c|c|c|c|}
\hline \multirow{2}{*}{ Adsorbent } & \multicolumn{4}{|c|}{ Flow rate $\left(\mathrm{ml} \mathrm{min}^{-1}\right)$} \\
\hline & 50 & 60 & 70 & 80 \\
\hline \multicolumn{5}{|c|}{$0.2 \mathrm{~g}$} \\
\hline $\begin{array}{l}\text { First order } \\
\mathrm{k}\left(\min ^{-1}\right)\end{array}$ & $\begin{array}{l}\mathrm{k}=0.0048 \\
\mathrm{R}^{2}=0.661\end{array}$ & $\begin{array}{r}\mathrm{k}=0.0060 \\
\mathrm{R}^{2}=0.703\end{array}$ & $\begin{array}{c}\mathrm{k}=0.0067 \\
\mathrm{R}^{2}=0.749\end{array}$ & $\begin{array}{c}\mathrm{k}=0.0080 \\
\mathrm{R}^{2}=0.866\end{array}$ \\
\hline $\begin{array}{l}\text { Adams-Bohart, } \mathrm{k}_{\mathrm{AB}} \\
\left(\mathrm{cm}^{3} \mathrm{~g}^{-1} \mathrm{~min}^{-1}\right)\end{array}$ & $\begin{array}{l}\mathrm{k}_{\mathrm{AB}}=22828 \\
\mathrm{R}^{2}=0.715\end{array}$ & $\begin{array}{l}\mathrm{k}_{\mathrm{AB}}=45870 \\
\mathrm{R}^{2}=0.688\end{array}$ & $\begin{array}{l}\mathrm{k}_{\mathrm{AB}}=57390 \\
\mathrm{R}^{2}=0.708\end{array}$ & $\begin{array}{l}\mathrm{k}_{\mathrm{AB}}=61135 \\
\mathrm{R}^{2}=0.691\end{array}$ \\
\hline $\begin{array}{c}\text { Yoon-Nelson } \\
\mathrm{k}_{\mathrm{YN}}\left(\min ^{-1}\right) \\
\tau(\min ) \\
\end{array}$ & $\begin{array}{c}\mathrm{k}_{\mathrm{YN}}=0.0098 \\
\tau=230.4 \\
\mathrm{R}^{2}=0.866 \\
\end{array}$ & $\begin{array}{c}\mathrm{k}_{\mathrm{YN}}=0.0193 \\
\tau=189.9 \\
\mathrm{R}^{2}=0.954\end{array}$ & $\begin{array}{c}\mathrm{k}_{\mathrm{YN}}=0.0223 \\
\tau=170.5 \\
\mathrm{R}^{2}=0.982 \\
\end{array}$ & $\begin{array}{c}\mathrm{k}_{\mathrm{YN}}=0.0430 \\
\tau=145.9 \\
\mathrm{R}^{2}=0.999\end{array}$ \\
\hline \multicolumn{5}{|c|}{$0.3 \mathrm{~g}$} \\
\hline & 35 & 50 & 65 & 80 \\
\hline $\begin{array}{l}\text { First order } \\
\mathrm{k}\left(\min ^{-1}\right)\end{array}$ & $\begin{array}{c}\mathrm{k}=0.0011 \\
\mathrm{R}^{2}=0.683\end{array}$ & $\begin{array}{r}\mathrm{k}=0.0017 \\
\mathrm{R}^{2}=0.682\end{array}$ & $\begin{array}{c}\mathrm{k}=0.0022 \\
\mathrm{R}^{2}=0.457\end{array}$ & $\begin{array}{l}\mathrm{k}=0.0028 \\
\mathrm{R}^{2}=0.896\end{array}$ \\
\hline $\begin{array}{l}\text { Adams-Bohart, } \mathrm{k}_{\mathrm{AB}} \\
\left(\mathrm{cm}^{3} \mathrm{~g}^{-1} \mathrm{~min}^{-1}\right)\end{array}$ & $\begin{array}{l}\mathrm{k}_{\mathrm{AB}}=57686 \\
\mathrm{R}^{2}=0.771\end{array}$ & $\begin{array}{l}\mathrm{k}_{\mathrm{AB}}=12475 \\
\mathrm{R}^{2}=0.762\end{array}$ & $\begin{array}{l}\mathrm{k}_{\mathrm{AB}}=39084 \\
\mathrm{R}^{2}=0.724\end{array}$ & $\begin{aligned} \mathrm{k}_{\mathrm{AB}} & =77968 \\
\mathrm{R}^{2} & =0.717\end{aligned}$ \\
\hline $\begin{array}{c}\text { Yoon-Nelson } \\
\mathrm{k}_{\mathrm{YN}}\left(\mathrm{min}^{-1}\right) \\
\tau(\min )\end{array}$ & $\begin{aligned} \mathrm{k}_{\mathrm{YN}} & =0.0165 \\
\tau & =628.7 \\
\mathrm{R}^{2} & =0.882\end{aligned}$ & $\begin{array}{c}\mathrm{k}_{\mathrm{YN}}=0.0111 \\
\tau=591.3 \\
\mathrm{R}^{2}=0.893\end{array}$ & $\begin{aligned} \mathrm{k}_{\mathrm{YN}} & =0.0093 \\
\tau & =396.5 \\
\mathrm{R}^{2} & =0.936\end{aligned}$ & $\begin{aligned} \mathrm{k}_{\mathrm{YN}} & =0.0115 \\
\tau & =332.1 \\
\mathrm{R}^{2} & =0.986\end{aligned}$ \\
\hline
\end{tabular}

In some cases the Adams-Bohart model represented the date better than the first order kinetics model, as in the case of $0.2 \mathrm{~g}$ Zeolite at $60 \mathrm{ml} \mathrm{min}{ }^{-1}$. As shown in Tables 2, at these conditions, the coefficient of determination, $\mathrm{R}^{2}$, was determined to be 0.359 and 0.887 for first order and Adams-Bohart models, respectively. However, in other cases, the presentation of the first order was better, as in the case of $0.2 \mathrm{~g}$ DP-AC at $80 \mathrm{ml} \mathrm{min}{ }^{-1}$. As shown in Table 2, at these conditions, the coefficient of determination, $\mathrm{R}^{2}$, was determined to be 0.723 and 0.262 for first order and Adams-Bohart models, respectively. With an exponential of a positive equation, the Adams-Bohart model model was able to better present the initial part of the breakthrough curve well, but fails to follow the last part. On the other hand, the nature of the first order model equation, which is an exponential of a negative, allowed the model to present better the end part of the breakthrough curve well, but fails to follow the initial part. This initial part becomes more significant, as the LPG flow rate reduces or the bed height increases, which both result in increasing the time it takes for the first breakthrough to appear. Therefore, as shown in Tables 2-4, for first order model the values of $\mathrm{R}^{2}$ decreased as the amount of adsorbent increased or the flow rate decreased. However, unlike the other two adsorbents, the $\mathrm{R}^{2}$ values of the first order model fitting of DP-AC decreased with the increase in the amount of adsorbent. For the Adams-Bohart model, an opposite trend was observed. One can conclude that it would be better to use the first order kinetics to model a system if the bed height is large, and low flow rate is low. Whereas, the Adams-Bohart model would be better if the bed height is small and the flow rate is high.
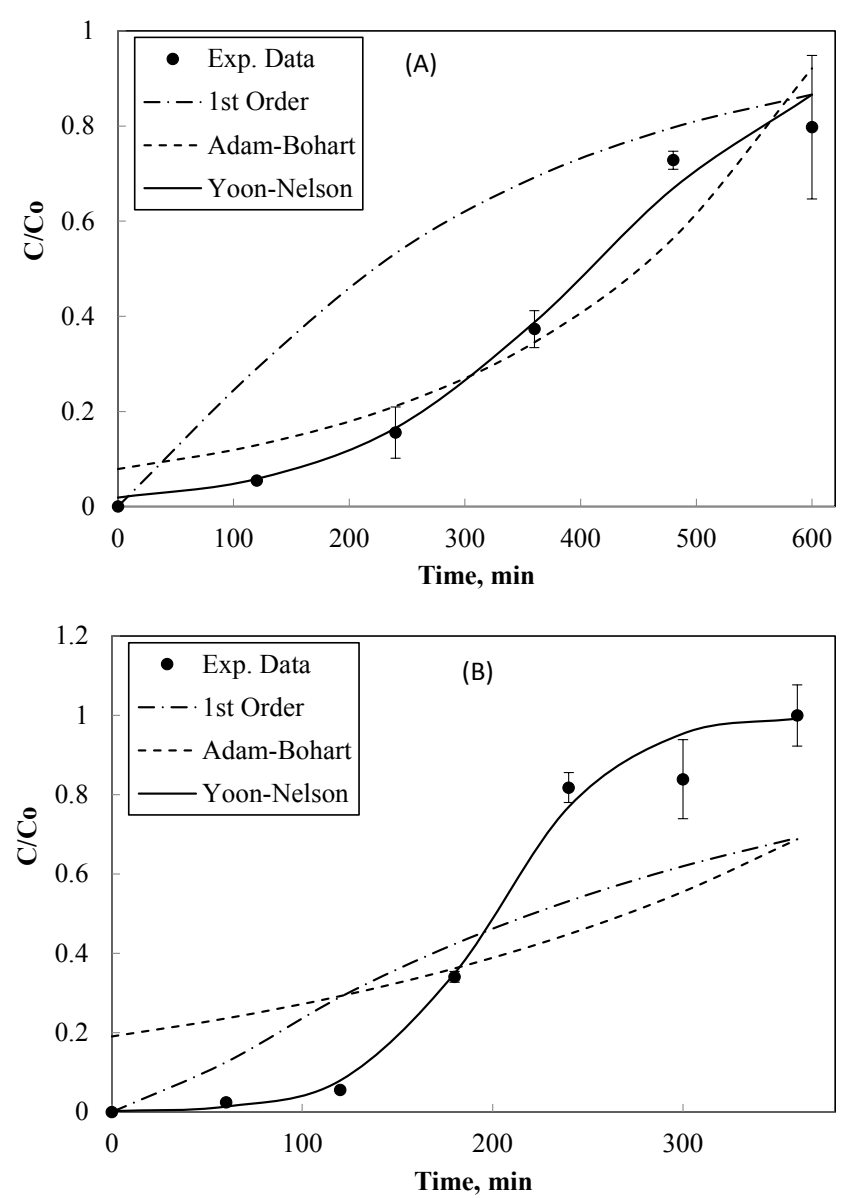

Figure 5. Models predictions of the fraction of EM output concentration per input concentration using $0.2 \mathrm{~g}$ Zeolite at (A) $60 \mathrm{ml} \mathrm{min}^{-1}$ and (B) 80 $\mathrm{ml} \mathrm{min}{ }^{-1}$ 

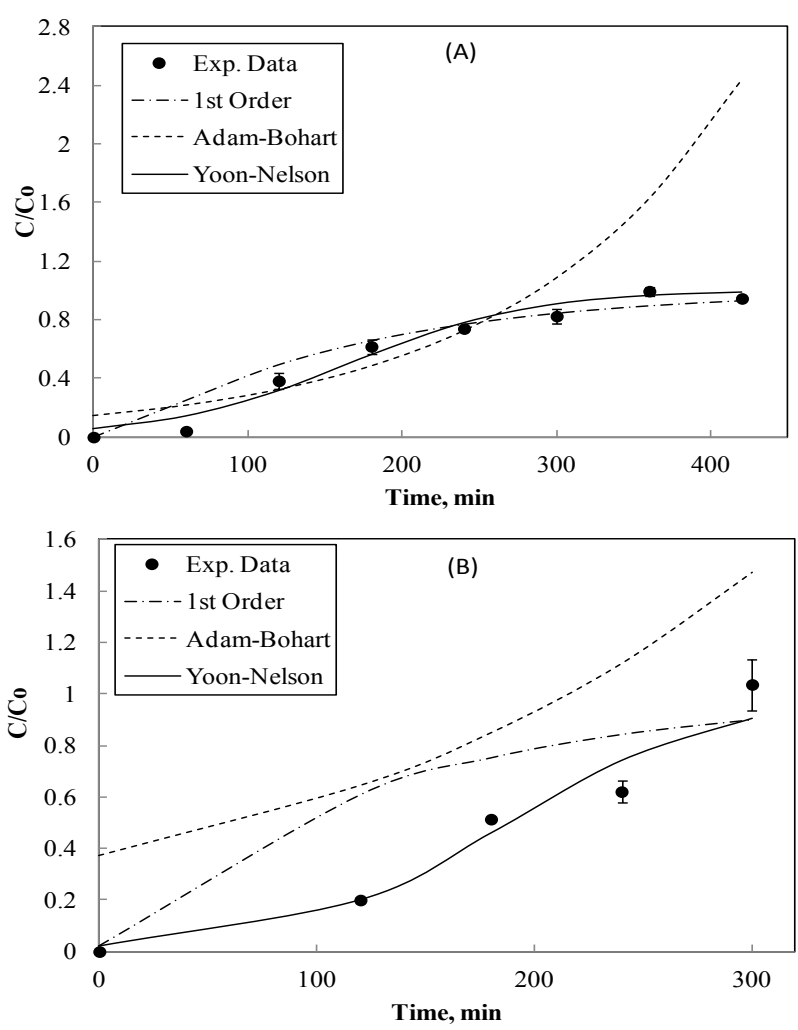

Figure 6. Models predictions of the fraction of EM output concentration per input concentration using $0.2 \mathrm{~g} \mathrm{DP}-\mathrm{AC}$ at (A) $60 \mathrm{ml} \mathrm{min}^{-1}$ and (B) 80 $\mathrm{ml} \mathrm{min} \operatorname{mon}^{-1}$
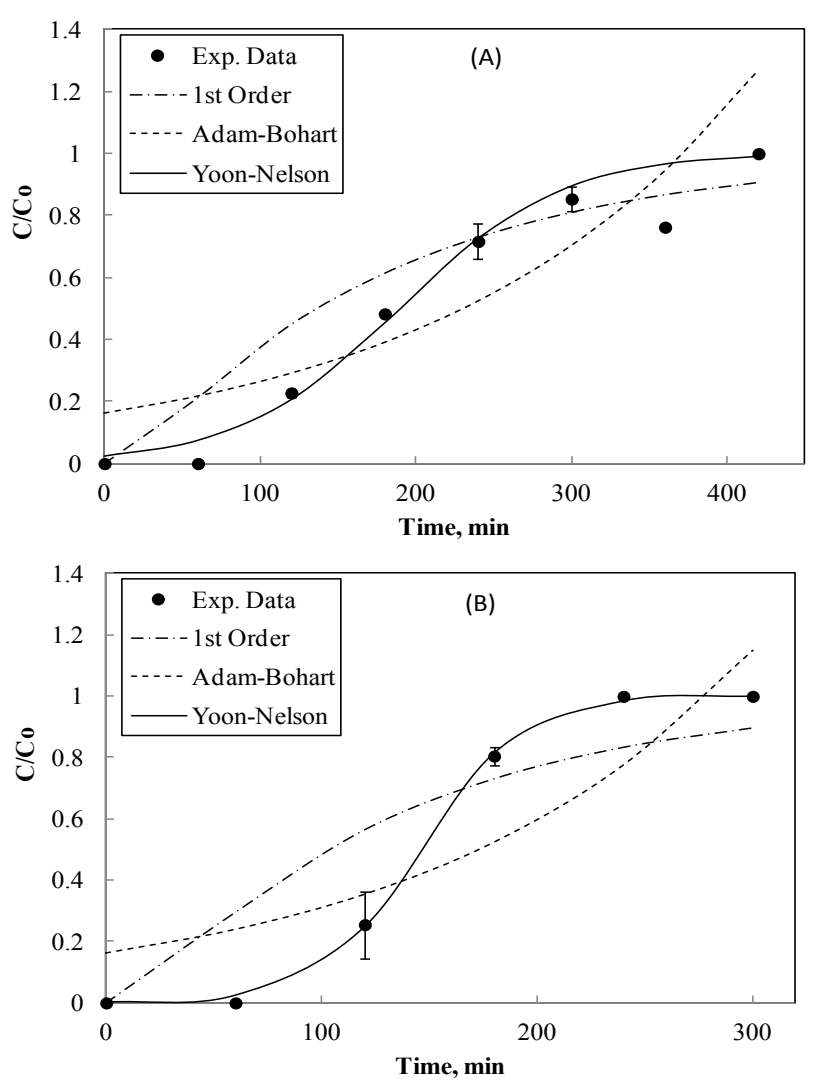

Figure 7. Models predictions of the fraction of EM output concentration per input concentration using $0.2 \mathrm{~g} \mathrm{ZnO}$ at (A) $60 \mathrm{ml} \mathrm{min}^{-1}$ and (B) $80 \mathrm{ml}$ $\min ^{-1}$
Generally, the Adams-Bohart model presented the data better than the first order model, with average values of $\mathrm{R}^{2}$, for all cases shown in Tables 2-4, of $0.738 \pm 0.21,0.633 \pm$ 0.2 and $0.722 \pm 0.03$ for Zeolite, DP-Ac and $\mathrm{ZnO}$, respectively, which are higher than those found for the first order model. Nevertheless, the model was still unable to follow the sigmoidal behavior of the adsorption front, as shown in Figures 5-7.

\section{B. Yoon-Nelson model}

The third tested model was the Yoon-Nelson model [12], given in $\mathrm{Eq}$ (4), which has two adjustable parameters

$$
\frac{\mathrm{C}_{\mathrm{L}}}{\mathrm{C}_{\mathrm{in}}-\mathrm{C}_{\mathrm{L}}}=\exp \left[\mathrm{k}_{\mathrm{YN}}(\mathrm{t}-\tau)\right]
$$

Where, $\mathrm{k}_{\mathrm{YN}}$ is the rate constant $\left(\mathrm{min}^{-1}\right)$ and $\tau$ is the time required for $50 \%$ adsorbate breakthrough $(\mathrm{min})$. The parameters of $\mathrm{k}_{\mathrm{YN}}$ and $\tau$ were determined, for the three adsorbents at different flow rates, by the least square method. Excel solver was used to minimize the summation of the difference between the squares of the experimental and predicted values of $C_{L} / C_{i n}$. The determined $k_{Y N}$ and $\tau$ values are presented in Tables 2-4 for Zeolite, DP-AC and $\mathrm{ZnO}$, respectively. Graphical outputs showing the fits of the experimental data by the Yoon-Nelson model are shown in Figures 5-7, for $0.2 \mathrm{~g}$ adsorbent at 60 and $80 \mathrm{ml} \mathrm{min}^{-1}$ using Zeolite, DP-AC and $\mathrm{ZnO}$, respectively. It is clearly seen that the Yoon-Nelson model predicts the experimental data much better than the previous two models. In addition, it was able to follow the sigmoidal behavior of the adsorption front, and the goodness of fitting was reflected on the values of the coefficients of determination, $\mathrm{R}^{2}$, which have average values of $0.980 \pm 0.01,0.968 \pm 0.02$ and $0.937 \pm 0.05$ for Zeolite, DP-AC and $\mathrm{ZnO}$, respectively. Since in the Yoon-Nelson model two different adjustable parameters were used, it is expected to show a better fit the experimental data. It was observed that the value the $\mathrm{k}_{\mathrm{YN}}$, did not show any clear trend towards flow rate, but similar to $\mathrm{k}$ and $\mathrm{k}_{\mathrm{AB}}$, they generally decreased with the increase in the amount of adsorbent. However, the time required for $50 \%$ adsorbate breakthrough, $\tau$, showed a very clear trend with the increase in flow rate and amount of adsorbents. It was found that the time required for $50 \%$ adsorbate breakthrough, $\tau$, decreased with the increase in LPG flow rate. This is mainly due to the increase in the input rate of sulfur molecules that results in a faster bed saturation. On the other hand, $\tau$ increased with the increase in the amount adsorbents, which is due to the increase in active cites available that require longer time to get saturated.

\section{Conclusions}

Continuous adsorption of EM, found in LPG, in a fixed bed column was performed. The adsorption efficiency and bed capacity of Zeolite, DP-AC and $\mathrm{ZnO}$ were evaluated at 
different adsorbents weights and LPG flow rates. The surface characteristics of the three adsorption were also determined. Zeolite and DP-AC showed typical features of microporous materials, whereas $\mathrm{ZnO}$ surface was dominated by mesopores with negligible amount of micropores. The EM adsorption experiment showed that the capacity of DP-AC did not change with the amount of adsorbent used, whereas it did for Zeolite and $\mathrm{ZnO}$. Increasing the flow rate had an insignificant effect on the capacity of DP-AC and Zeolite, but reversibly affected that of $\mathrm{ZnO}$, due to their larger micropore volumes and smaller average pores sizes, compared to $\mathrm{ZnO}$. First order, Adams-Bohart and Yoon-Nelson models were used to fit the breakthrough experimental data at different LPG flow rates and adsorbents amounts. The first order kinetics model presented the system better than Adams-Bohart model when the bed height was large and the flow rate was low. Whereas, the Adams-Bohart model was better when the bed height was small and the flow rate was high. However, both models did not give good fittings, and only the Yoon-Nelson model was able to follow the sigmoidal behavior of the adsorption front.

\section{Acknowledgements}

The authors would like to acknowledge the financial support provided by the Japan Cooperation Center, Petroleum (JCCP) (Fund No. 21N125) and the technical support of the JX-NRI.

\section{REFERENCES}

[1] D. Crespo, G. Qi, Y. Wang, F.H. Yang, R.T. Yang, Superior sorbent for natural gas desulfurization, Industrial Engineering Chemistry Research, 2008, Vol. 47, 1238-1244.

[2] A.L. Kohl, R. Nielson, Gas purification. $5^{\text {th }}$ Ed, Houston Gulf Publishing Co., 1997.

[3] S. Al-Zuhair, A. Khalil, M. Hassan, A. Abdulrazak, K. Basil, A. Fardoun. Performance Evaluation of LPG Desulfurization by Adsorption for Hydrogen Production, Journal of Energy Chemistry, 2015, Vol. 24, 477-484

[4] M. Jiang, T.T. Flora, A. Rahman, V. Patel, Flow calorimetric and thermal gravimetric study of adsorption of thiophenic sulfur compounds on NaY Zeolite, Thermochimica Acta, 2005, Vol. 434, 27-36

[5] L. Lidan, J. Zhang, C. Huang, Z. Lei, B. Chen. Adsorptive separation of dimethyl disulfide from liquefied petroleum gas by different Zeolites and selectivity study via FT-IR, Separation and Purification Technology, 2014, Vol. 125, 247-255

[6] E. Vega, J. Lemus, A. Anfruns, R. Gonzalez-Olmos, J. Palomar, Adsorption of volatile sulphur compounds onto modified activated carbons: Effect of oxygen functional groups, Journal of Hazardous Materials, 2013, Vol. 258, $77-83$

[7] J. Wen, X. Han, H. Lin, Y. Zheng, W. Chu. A critical study on the adsorption of heterocyclic sulfur and nitrogen compounds by activated carbon: Equilibrium, kinetics and thermodynamics, Chemical Engineering Journal, 2010, Vol. $164,29-36$

[8] J.H. Kim, X. Ma, A. Zhou, C. Song, Ultra-deep desulfurization and denitrogenation of diesel fuel by selective adsorption over three different adsorbents: A study on adsorptive selectivity and mechanism, Catalysis Today, 2006, Vol. 111, 74-83

[9] K.K. Sarda, A. Bhandari, K.K. Pant, Deep desulfurization of diesel fuel by selective adsorption over $\mathrm{Ni} / \mathrm{Al}_{2} \mathrm{O}_{3}$ and Ni/ZSM-5 extrudates, Fuel, 2012, Vol. 93, 86-91

[10] S.K. Gangwal, Desulfurization for Fuel Cells, in: D. Shekhawat, J.J. Spivey, D.A. Berry, eds, Fuel Cells: Technologies for Fuel Processing, Elsevier, 2011, 317-360

[11] G.S. Bohart, E.Q. Adams, Behavior of charcoal towards chlorine, Journal of the American Chemical Society, 1920, Vol. 42, 523-529

[12] Y.H. Yoon, J.H. Nelson, Application of gas adsorption kinetics. Part I. A theoretical model for respirator catridge service time, American Industrial Hygiene Association Journal, 1984, Vol. 45, 509-516

[13] D.M. Ruthven, Principles of Adsorption and Adsorption Processes. John Wiley \& Sons, New York, 1984.

[14] D. Wang, E. McLaughlin, R. Pfeffer, Y.S. Lin, Aqueous phase adsorption of toluene in a packed and fluidized bed of hydrophobic aerogels, Chemical Engineering Journal, 2011, Vol. 168, 1201-1208

[15] N. Wakao, T. Funazkri, Effect of fluid dispersion coefficients on particle-to-fluid mass transfer coefficients in packed beds: correlation of Sherwood numbers. Chemical Engineering Science. 1978, Vol. 33, 1375-1384. 